\title{
Notes on the floral biology and pollination syndrome of Echinopsis chiloensis (Colla) Friedrich \& G.D.Rowley (Cactaceae) in a population of semiarid Chile
}

\section{Notas sobre la biología floral y síndrome de polinización de Echinopsis chiloensis (Colla) Friedrich \& G.D.Rowley (Cactaceae) en una población de Chile semiárido}

\author{
Carmen G. Ossa \& Rodrigo Medel* \\ Departamento de Ciencias Ecológicas, Facultad de Ciencias, Universidad de Chile, Santiago, Chile. \\ *rmedel@uchile.cl
}

\begin{abstract}
We report some aspects of the floral biology of Echinopsis chiloensis ssp. chiloensis in a population near to the northern limit of its distribution. Anthesis is strictly diurnal and flowers remain open during $492 \mathrm{~min}$ on the average. Echinopsis chiloensis is self-incompatible. Flower longevity, nectar production along day, and floral visitors indicate that this population fits well to a diurnal insect pollination syndrome. These results contrast with a previous report indicating nocturnal anthesis and mixed mellitophylous-sphingophylous pollination syndrome in populations near to the southern limit of the distribution range. We suggest that the pollination syndrome of $E$. chiloensis is a labile rather than fixed condition that may depend on the abiotic characteristics and geographical location of the population under assessment.
\end{abstract}

KEYwoRDs: Flower longevity, nectar production, pollination syndrome, flower adaptation.

\section{RESUMEN}

Documentamos algunos aspectos de la biología floral de Echinopsis chiloensis ssp. chiloensis en una población del límite norte de su rango de distribución. La antesis es estrictamente diurna y las flores permanecen abiertas durante 492 min en promedio. La especie es auto incompatible. La longevidad floral, la marcha de néctar y los registros de polinizadores indican que la población de E. chiloensis se ajusta bien a un síndrome de polinización por insectos diurnos, lo cual contrasta con la antesis nocturna y el síndrome mixto melitófilo-esfingófilo descrito en poblaciones del límite sur de la distribución de la especie. Sugerimos que el síndrome de polinización de E. chiloensis es lábil y no fijo, siendo dependiente de la población bajo estudio y de su ubicación geográfica.

Palabras clave: Longevidad floral, producción de néctar, síndrome de polinización, adaptación floral.

\section{INTRODUCTION}

Pollination syndromes are useful categorizations to understanding floral diversification because they permit classification of pollinators according to putative similarities in the selection forces they impose on the flower phenotype (Fenster et al. 2004). Most columnar cacti are hermaphrodite plants that strongly depend on animals for reproduction (Gibson \& Nobel 1986). While columnar cacti often rely on bats as pollinators in the tropics (e.g., Nassar et al. 1997, Fleming \& Valiente-Banuet 2002, Ibarra-Cerdeña et al. 2005), more generalized and mixed pollination syndromes have been suggested to be prevalent in temperate ecosystems (Fleming et al. 1996, 2001, Valiente-Banuet et al. 2002). The few studies performed on pollination syndromes in extra-tropical South America provide support to such generalization. For example Valiente-Banuet et al. (2004) reported that flowers of Pachycereus pecten-aboriginum (Engelm. ex S. Watson) Britton \& Rose in tropical Mexican populations open at night and close early in the morning, the nectar is secreted only during the night, and pollination is restricted to bats. In northern populations, anthesis and nectar secretion occur indistinctly during the night and day, allowing the visitation and effective pollination by both nocturnal and diurnal pollinators. In Perú, the anthesis of Weberbanerocereus weberbaueri (K. Schum. ex Vaupel) Backeb. is nocturnal, and pollination occurs mainly by bats and hummingbirds in severe drought conditions (Sahley 1996). In Bolivia, in spite of the extensive anthesis period that covers diurnal and nocturnal, Oreocereus celsianus (Lem. 
ex Salm-Dyck) Riccob. is pollinated almost exclusively by hummingbirds (Larrea-Alcázar \& López 2011). In Argentina, Echinopsis atacamensis (Phil.) Friedrich \& G.D.Rowley ssp. pasacana (F.A.C.Weber) G. Navarro is visited by diurnal and nocturnal animals, including bees, moths and birds (de Viana et al. 2001, Schlumpberger \& Badano 2005), and Echinopsis terscheckii (Parm. ex Pfeiff.) Friedrich \& G.D. Rowley, a species with nocturnal and diurnal flowers that open at dusk and close the next day, is visited by moths, bees, and birds, being moths the most efficient pollinators (Ortega-Baes et al. 2011). Unlike the species indicated above, Echinopsis ancistrophora Speg. presents diurnal or nocturnal anthesis depending on the population, and their flowers are pollinated by bees and hawkmoths (Schlumpberger et al. 2009). Recently, Walter (2010) described that, contrary to previous reports indicating diurnal anthesis (Hoffmann 1989, Hoffmann \& Walter 2004), flowers of Echinopsis chiloensis (Colla) Friedrich \& G.D.Rowley open at dusk and have a long longevity (17 - 42 h), which permits a mixed pollinator (bees and hawkmoths) syndrome in populations near to the southern distribution limit of the species. In this note we report some aspects of the floral biology of Echinopsis chiloensis ssp. chiloensis that confirm the existence of strict diurnal anthesis in a population near to the northern limit of the distribution range of the species. By doing so, we provide data on the breeding system, flower longevity, and flower visitors of E. chiloensis in a different environmental setting than that provided by Walter (2010) and discuss the consequences of this finding.

\section{MATERIALS AND METHODS}

This study was conducted during November 2006 at the National Reserve Las Chinchillas ( $31^{\circ} 30^{\prime}$ S, $71^{\circ} 06^{\prime}$ W), located $300 \mathrm{~km}$ northeast of Santiago. The climate is of a semiarid Mediterranean type with most rainfall concentrated in the winter season. Mean annual precipitation is 167 mm (data from 1974 to 1999), with ample inter-annual variation and long-lasting droughts alternated with unusual years of high precipitation that seemingly co-occur with ENSO events (Jaksic 2001). The reproductive season of E. chiloensis extends from early September through midNovember. Vegetation in the study site is thorny, with Flourensia thurifera DC. (Asteraceae), Bahia ambrosioides Lag. (Asteraceae), and Porlieria chilensis I.M.Johnst. (Zygophyllaceae) as the most common shrub species. In the study site, E. chiloensis is parasitized extensively by the leafless mistletoe Tristerix aphyllus (Miers ex DC.) Barlow \& Wiens (Medel et al. 2004). Additional cactus species are represented by the columnar Eulychnia acida Phil., and the spheric-shaped Cumulopuntia sphaerica (Foerster) E.F. Anderson and Eriosyce aurata (Pfeiff.) Backeb.
A total of 43 flowers were tagged and monitored on an hourly basis during 4 consecutive days to determine flower longevity. Temperature was recorded with a thermocouple adhered to the cactus surface and oriented in the NW exposition. Nectar volume was measured on 20 previously bagged flower buds in an independent set of plants. Nectar was collected using $1 \mathrm{ml}$-microcapillars, every hour after flower opening until withering. To record potential pollinators, we performed focal observations of $30 \mathrm{~min}$ in 26 flowers from independent plants during 5 sunny days. Insects that entered the tubular hypanthium and contacted the reproductive organs of the flower were considered as flower visitors. All observations were performed between 8:30 - 16:00 h. Samples of flower visitors were collected at the end of the 5-day observation period for subsequent identification in the laboratory.

To determine the breeding system, we tagged flower buds from different cacti, and assigned them to one of the following treatments: (1) natural pollination ( $\mathrm{N}=40$ flowers): flowers entirely available to visitors; (2) autonomous selfpollination $(\mathrm{N}=84$ flowers): pollinators excluded from flowers with white tulle bags, flowers without manipulation; (3) manual self-pollination ( $\mathrm{N}=47$ flowers): pollinators excluded from flowers, stigmas fertilized with pollen of the same flower; (4) manual cross-pollination ( $\mathrm{N}=55$ flowers): pollinators excluded from flowers, flowers emasculated, and stigmas fertilized with pollen of plants distant at least 5 $\mathrm{m}$ from the focal plant. Experiments were performed in the morning to ensure that stigmas were receptive and pollen was viable. We evaluated the outcome of treatments on: (a) fruit production or abortion (1/0), and (b) seed production of fruits. Treatment effects on dependent variables were examined in GLM using a binomial distribution for residuals and a logit-link function for independent and dependent variables. Coefficients were estimated using maximum likelihood. We calculate the index of self-incompatibility (ISI) proposed by Ruiz-Zapata and Arroyo (1978), which indicates the physiological capacity to carry out the selffecundation. The index was calculated by dividing the number of seeds produced by manual self-pollination (treatment 3 ) and the number of seeds produced by manual cross-pollination (treatment 4). The index indicates selfincompatibility in the range $0-0.2$, partial or incomplete self-compatibility when $0.2<$ ISI value $<1$, and complete self-compatibility when ISI $=1$.

\section{RESULTS}

The flowers of E. chiloensis are funnel-shaped and displayed in lateral or apical position on the columns. Like most flowers in the genus, the flowers are tubular, external tepals are green and the internal tepals are white. Flowers are hermaphroditic with a lobed stigma that most of the 
time exceeds the height of anthers (mean style length $=$ $90.4 \mathrm{~mm}$, mean height of the highest stamen $=74.7 \mathrm{~mm}$ ). In general, flowers tend to be smaller than reported in southern populations by Walter (2010) (range flower length: 107 - 153 $\mathrm{mm}$ and $140-160 \mathrm{~mm}$, respectively). The flowers began to open between 07:00 - 08:00 $\mathrm{h}$ when the temperature reaches $10^{\circ} \mathrm{C}$ (Fig. 1a). The ratio of open flowers increased quickly from 0.29 at 07:00 - 08:00 to 0.97 at 09:00 - 10:00 h, when the air temperature is over $15^{\circ} \mathrm{C}$. After that, the ratio remains relatively stable until 14:00 h (temperature above $33^{\circ} \mathrm{C}$ ) when most flowers begin to close. No flower was open later than 17:00 $\mathrm{h}$. Overall, individual flowers do not live for more than 492 min on the average ( $\mathrm{SD}=101$ ), and do not re-open after closing. The daily pattern of nectar production showed two well-defined picks in the intervals 07:00 - 11:00 $\mathrm{h}$ and one additional pick at 15:00 - 16:00 h (Fig. 1b). The lowest nectar production occurred in the interval 17:00 - 18:00 $\mathrm{h}$ after flowers experienced the maximum temperature $\left(35^{\circ} \mathrm{C}\right)$ (Fig. 1a, Fig. 1b). Flowers produced $54.1 \mu \mathrm{L}$ of nectar along day on the average $(\mathrm{SD}=49.5$, range $=0-173 \mu \mathrm{L}, \mathrm{N}=20$ ).

The chance of fruit production differed among the four reproductive treatments $\left(\mathrm{N}=226, \mathrm{df}=3, \chi^{2}=181.4, P<\right.$ 0.001 ) (see Table I). The flowers subject to autonomous self-pollination test produced less fruits than control flowers $1.2 \%$ vs. $90.0 \%$, respectively $\left(\mathrm{df}=1, \chi^{2}=114.3, P<0.001\right)$, indicating that pollen vectors are necessary for successful fertilization. The flowers subjected to manual crosspollination had a higher fruit production than flowers subject to manual self-pollination tests ( $76.4 \%$ vs $4.2 \%$, respectively, $\left.\mathrm{df}=1, \chi^{2}=101.0, P<0.001\right)$. This result is consistent with the low self-incompatibility index (0.043), suggesting a physiologic self-incompatibility in E. chiloensis.
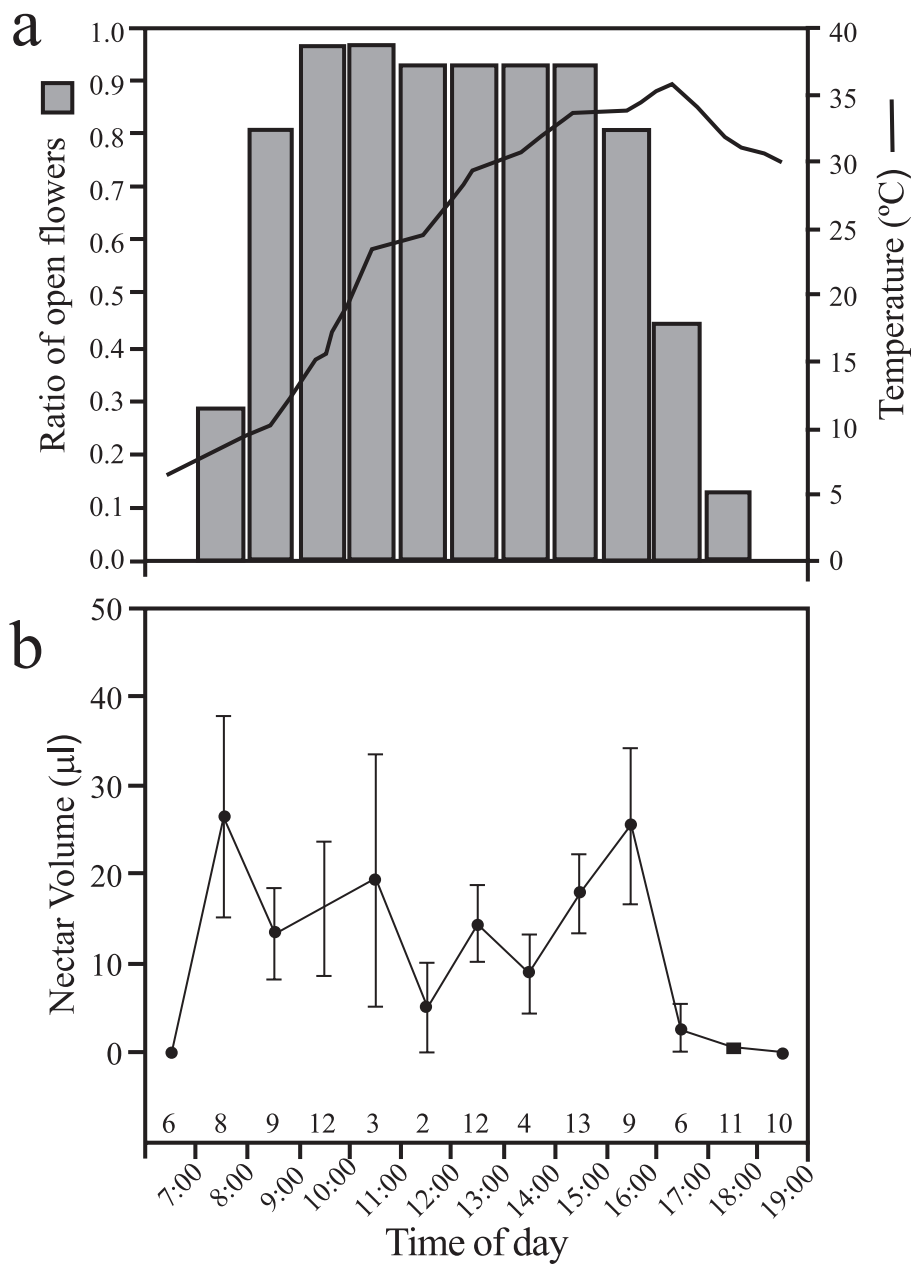

Figure 1. a) Ratio of open flowers of Echinopsis chiloensis as a function of the time of day. Continuous line indicates the mean temperature observed at each time interval. b) Mean nectar volume ( $\pm 1 \mathrm{SE})$ along day. Data obtained from 20 bagged flowers from independent plants. Values on the $\mathrm{x}$-axis indicate the number of flowers measured at each time interval.

Figura 1. a) Razón de flores abiertas de Echinopsis chiloensis en función de la hora del día. La línea continua indica el promedio de temperatura observado en cada intervalo de tiempo. b) Promedio ( $\pm 1 \mathrm{EE})$ del volumen de néctar en 20 flores de plantas independientes a lo largo del día. Valores sobre la abscisa indican el número de flores medidas en cada intervalo horario. 
Regarding flower visitors, all the species recorded were insects, mainly hymenopterans ( 8 species) and dipterans (7 species), followed by coleopterans (3 species) and lepidopterans (1 species) (Table II). The flowers of $E$. chiloensis were more frequently visited by hymenopterans and dipterans than coleopterans and lepidopterans (Table II). Hymenopterans were more frequent visitors than dipterans (GLM estimates, mean \pm SE; hymenopterans: $2.81 \pm 0.28$; dipterans: $0.89 \pm 0.29, P<0.001)$. Within hymenopterans, there was a high heterogeneity in the visitation rate shown by species $\left(\mathrm{LL}=520.4, \chi^{2}=1040.8, \mathrm{df}=7, P<0.001\right)$, with
Caenohalictus and Megachile as the most important genera. The visitation rate of the exotic honeybee $A$. mellifera albeit lower than most hymenopterans, did not differ from the native $C$. nigerrima $\left(\chi^{2}=1.21, \mathrm{df}=1, P=0.270\right)$ and Trichoturgus sp $1\left(\chi^{2}=1.67, \mathrm{df}=1, P=0.196\right)$ (Table II). The overall pattern of activity of insects was unimodal, reaching its highest values between 11:00 - 13:00 h (Fig. 2). Unlike hymenopterans, dipterans presented two peaks of activity along day with an almost nil activity between 12:00 - 16:00 h (Fig. 2).

TABLE I. Summary of results for reproductive tests in Echinopsis chiloensis.

TABLA I. Resumen de los resultados de las pruebas reproductivas en Echinopsis chiloensis.

\begin{tabular}{llll}
\hline TeSt & Fruits/Flowers & SEEDS PER FrUit (SE) & SEEdS PER FLOWER (SE) \\
\hline Autonomous self-pollination & $1 / 84$ & $0^{\dagger}$ & $0^{\dagger}$ \\
Manual self-pollination & $2 / 47$ & $3408.0(922)$ & $145.0(105.2)$ \\
Manual cross-pollination & $42 / 55$ & $9449.7(279.3)$ & $3380.3(410.6)$ \\
Natural pollination & $36 / 40$ & $3040.1(286.8)$ & $2702.7(301.4)$ \\
\hline
\end{tabular}

$\uparrow$ Seeds not measured in the only fruit recovered./ Semillas no medidas en el único fruto recuperado.

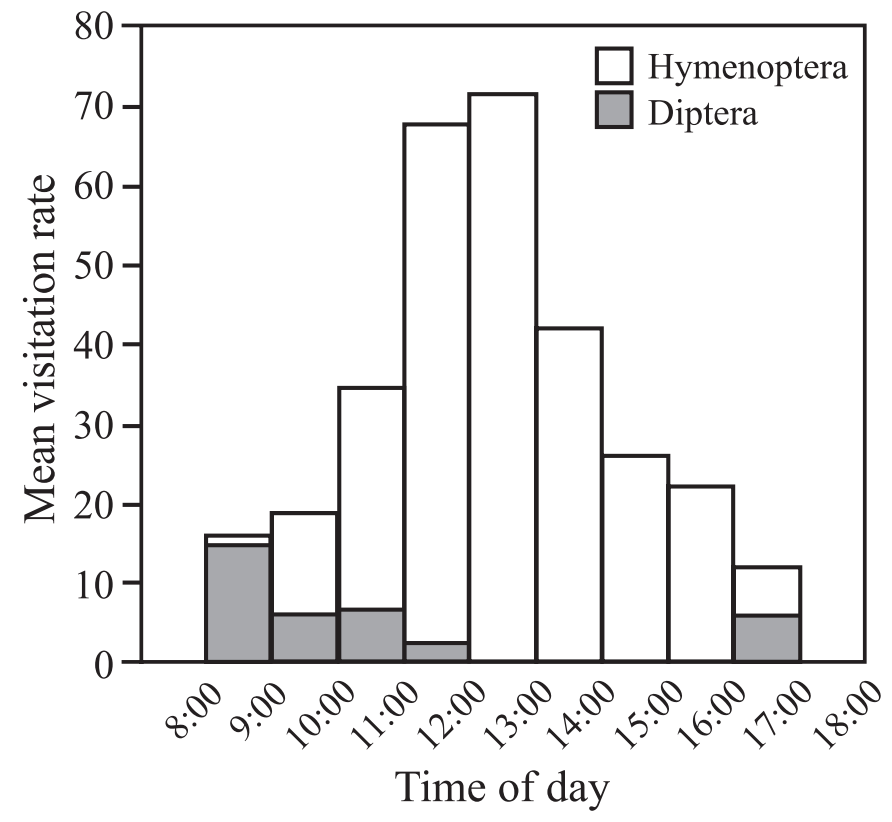

Figure 2. Mean visitation rate (visits flower ${ }^{-1} \mathrm{~h}^{-1}$ ) of hymenopterans and dipterans on individual flowers of Echinopsis chiloensis along day. Data on coleopteran and lepidopteran visits are not shown for simplicity (see Table II). Recordings based upon 30-min timed observations per flower.

Figura 2. Tasa promedio de visitas (visitas flor ${ }^{-1} \mathrm{~h}^{-1}$ ) de himenópteros y dípteros sobre flores individuales de Echinopsis chiloensis a lo largo del día. Los datos de visita de coleópteros y lepidópteros no se presentan en la figura para mayor simplicidad (ver Tabla II). Los registros se basaron en observaciones focales de $30 \mathrm{~min}$ por flor. 
TABLE II. List of flower visitors in Echinopsis chiloensis. Visitation rate is expressed as number of visits flower ${ }^{-1} \mathrm{~h}^{-1}$.

TABLA II. Lista de visitantes florales en Echinopsis chiloensis. La tasa de visitas es expresada como el número de visitas flor ${ }^{-1} \mathrm{~h}^{-1}$.

\begin{tabular}{|c|c|}
\hline ORDER/FAMILY/SPECIES & VisitATION RATE (SE) \\
\hline \multicolumn{2}{|l|}{ Hymenoptera } \\
\hline & \\
\hline \multicolumn{2}{|l|}{ Apis mellifera } \\
\hline Centris nigerrima & $0.10(0.08)$ \\
\hline \multicolumn{2}{|l|}{ Halictidae } \\
\hline Caenohalictus sp 2 & $14.73(5.01)$ \\
\hline Lasioglossum $\mathrm{sp}$ & $3.38(1.61)$ \\
\hline \multicolumn{2}{|l|}{ Megachilidae } \\
\hline Megachile saulcyi & $7.41(2.40)$ \\
\hline Trichoturgus sp 1 & $0.44(0.27)$ \\
\hline Trichoturgus sp 2 & $2.59(0.68)$ \\
\hline \multicolumn{2}{|l|}{ Diptera } \\
\hline \multicolumn{2}{|l|}{ Mycetophilidae } \\
\hline sp 1 & $0.26(0.16)$ \\
\hline sp 2 & $0.58(0.28)$ \\
\hline sp 3 & $2.88(0.98)$ \\
\hline \multicolumn{2}{|l|}{ Syrphidae } \\
\hline Copestylum concinna & $0.14(0.09)$ \\
\hline sp 1 & $0.08(0.08)$ \\
\hline sp 2 & $0.61(0.36)$ \\
\hline \multicolumn{2}{|l|}{ Sarcophagidae } \\
\hline $\mathrm{sp} 1$ & $0.08(0.08)$ \\
\hline \multicolumn{2}{|l|}{ Coleoptera } \\
\hline \multicolumn{2}{|l|}{ Scarabeidae } \\
\hline Arctodium vulpinus & $0.04(0.04)$ \\
\hline Lichnia gallardoi & $0.03(0.08)$ \\
\hline sp 1 & $0.08(0.08)$ \\
\hline \multicolumn{2}{|l|}{ Lepidoptera } \\
\hline sp 1 & $0.04(0.04)$ \\
\hline
\end{tabular}

\section{DISCUSSION}

Echinopsis chiloensis has been frequently described as an endemic columnar with white diurnal flowers (Hoffmann \& Walter 2004). However, recently Walter (2010) described a mixed pollination syndrome that, in addition to diurnal insects, included dusk pollination attributable to hawkmoth species, hence suggesting the interesting possibility of a new pollination syndrome for this species (see also Ortega-Baes et al. 2011 for Echinopsis terscheckii, and Schlumpberger \& Badano 2005 for Echinopsis atacamensis). Our results on anthesis time and flower longevity differ from data reported by Walter (2010), indicating that southern and northern populations of $E$. chiloensis differ substantially in floral traits. For example, while flowers in the southern populations open at dusk, and remain open by $17-42 \mathrm{~h}$, flowers in the northern population are strictly diurnal and last only $8 \mathrm{~h}$ on the average, which exclude hawkmoths as potential pollinators.
The observation that not all floral traits of $E$. chiloensis match the standard hawkmoth pollination syndrome (Walter 2010) can be explained, in part, by the fact that northern populations did not receive visits by hawkmoths during our observation period. In consequence, sphingids cannot be invoked as important selective agents for northern populations of $E$. chiloensis. Other diurnal but unfrequent flower visitors, however, could have been undetected in our study. For example, the Chilean mockingbid Mimus thenca has been observed introducing its head into flowers of $E$. chiloensis in the study site (Medel, pers. obs.). Similarly, although hummingbirds are present at the study site (Patagonas gigas and Sephanoides sephaniodes), they have not been detected visiting flowers of $E$. chiloensis during more than 10 years of research in the site.

Because the physiological characteristics of flowers are generally thought to be adaptations to local environmental conditions in ways that ensure fertilization, it is likely that the discrepancy of our results with that of Walter (2010) 
comes from variation in abiotic factors between sites. For instance, while southern populations receive an annual precipitation of 450 - $500 \mathrm{~mm}$ (Walter 2010), the population from Las Chinchillas receives an mean annual precipitation of $167 \mathrm{~mm}$ on the average. Similarly, the maximum daily temperature at Las Chinchillas is $5^{\circ} \mathrm{C}$ higher than the southern populations. It is well known that temperature is one of the main factors determining the duration of anthesis (Primack 1985). It is likely that the high temperature and low water availability at Las Chinchillas impose physiological costs associated with flower development and anthesis to maternal plants, therefore promoting short-lived flowers as a way to circumvent abiotic constraints (see models in Ashman \& Schoen 1994, 1996). In consequence, it is likely that the variable floral traits observed in E. chiloensis results from variation in flower longevity among populations.

An alternative explanation relies on the observation that in arid Chilean areas, pollination by moths may be low or even absent in comparison to humid and high elevation localities (Pérez et al. 2006). In the absence of nocturnal pollinators, probably northern populations of $E$. chiloensis shifted towards exclusively diurnal flowers. This phenomenon may not be only restricted to E. chiloensis. For instance, Valiente-Banuet et al. (2004) showed that variation in the time of anthesis across the geographic range of the columnar species Pachycereus pecten-aboriginum, can be explained by variation in the pollinator availability among populations. Similarly, Schlumpberger et al. (2009) described that depending of the population; Echinopsis ancsistrophora may show diurnal, short, and bee-pollinated flowers, or alternatively, nocturnal, long, and hawkmothpollinated flowers. Our results on E. chiloensis show a similar phenomenon. While flowers of southern populations are nocturnal, long, and bee- and hawkmoth-pollinated, flowers in the northern population are diurnal, short, and mostly probably bee-pollinated. More work is needed to fully appreciate the ecological and evolutionary consequences of among-population variation in the floral biology of $E$. chiloensis. The extent to which abiotic and biotic factors, or a combination of them, influence the geographic variation in anthesis, flower longevity, and pollination syndromes in E. chiloensis need to be assessed in future studies.

\section{ACKNOWLEDGMENTS}

We thank Rigoberto Montero and Norita Peña for their collaboration during fieldwork and Daniel Tapia for helping with insect identification. Carezza Botto and two anonymous reviewers of Gayana Botanica made important suggestions that improved the clarity of this manuscript. This research was indirectly supported by Grants FONDECYT 1010660 , PSD 66, and ACT 34/2006 to RM. CONAF IV Region provided important logistic support during this research.

\section{LITERATURE CITED}

Ashman, T.L. \& D.J. Schoen. 1994. How long should flowers live? Nature 371: 788-791.

Ashman, T.L \& D.J. Schoen. 1996. Floral longevity: fitness consequences and resource costs. In: D.G. Lloyd \& S.C.H. Barrett (eds.), Floral biology. pp 112-139. Chapman and Hall, New York.

De Viana, M.L., P. Ortega-Baes, M. Saravia, E.I. Badano \& B. SChlumpBerger. 2001. Biología floral y polinizadores de Trichocereus pasacana (Cactaceae). Journal of Tropical Biology 49: 277-283

Fenster, C.B., W.S. Armbruster, P. Wilson, M.R. Dudash \& J.D. Thomson. 2004. Pollination syndromes and floral specialization. Annual Review of Ecology, Evolution and Systematics 35: 375-403.

Fleming, T.H., \& A. Valiente-Banuet (eds). 2002. Columnar cacti and their mutualists: evolution, ecology, and conservation. University of Arizona Press, Tucson. 371 pp.

Fleming, T.H., M.D. Tuttle \& M.A. Horner. 1996. Pollination biology and the relative importance of nocturnal and diurnal pollinators in three species of Sonoran Desert columnar cacti. Southwestern Naturalist 41: 257-269.

Fleming, T.H., C.T. Sahley, J.N. Holland, J.D. Nason \& J.L. HAMrICK. 2001. Sonoran desert columnar cacti and the evolution of generalized pollination systems. Ecological Monographs 71: 511-530.

Gibson, A.C. \& P.S. Nobel. 1986. The cactus primer. Harvard University Press, Cambridge. 286 pp.

Hoffmann, A.E. 1989. Cactáceas en la flora silvestre de Chile (Primera Edición). Ediciones Fundación Claudio Gay, Santiago, Chile. 272 pp.

Hoffmann, A.E. \& H.E. Walter. 2004. Cactáceas en la flora silvestre de Chile (2da Ed.). Ediciones Fundación Claudio Gay, Santiago. 307 pp.

Ibarra-Cerdeña, C.N., L.I. Iñiguez-Dávalos \& V. SánchezCordero. 2005. Pollination ecology of Stenocereus queretaroensis (Cactaceae), a chiropterophilous columnar cactus, in a tropical dry forest of Mexico. American Journal of Botany 92: 503-509.

JAKSIC, F.M. 2001. Ecological effects of El Niño in terrestial ecosystems of western South America. Ecography 24: 241-250.

Larrea-Alcázar, D.M. \& R.P. LóPez. 2011. Pollination biology of Oreocereus celsianus (Cactaceae), a columnar cactus inhabiting the high subtropical Andes. Plant Systematics and Evolution 295: 129-137.

Medel, R., E. Vergara, A. Silva \& M. Kalin-Arroyo. 2004. Effects of vector behavior and host resistance on mistletoe aggregation. Ecology 85: 120-126.

Nassar, J.M., N. Ramírez \& O. Linares. 1997. Comparative pollination biology of Venezuelan columnar cacto and the role of nectar-feeding bats in their sexual reproduction. American Journal of Botany 84: 918-927.

Ortega-Baes, P., M. Saravia, S. Suhring, H. Godínez-Alvarez \& M. ZAMAR. 2011. Reproductive biology of Echinopsis terscheckii (Cactaceae): the role of nocturnal and diurnal pollinators. Plant Biology 13: 33-40.

Pérez, F., M.T.K. Arroyo, R. Medel \& M.A. Hershkovitz. 2006. Ancestral reconstruction of flower morphology and 
pollination systems in Schizanthus (Solanaceae). American Journal of Botany 93: 1029-1038.

Primack, R.B. 1985. Longevity of individual flowers. Annual Review of Ecology and Systematics 16: 15-37.

Ruiz-Zapata, T. \& M.T.K. Arroyo. 1978. Plant reproductive biology of a secondary deciduous forest in Venezuela. Biotropica 10: 221-230.

SAHLEY, C.T. 1996. Bat and hummingbird pollination of an autotetroploid columnar cactus, Weberbauerocereus weberbaueri (Cactaceae). American Journal of Botany 83: 1329-1336.

Schlumpberger, B.O. \& E.I. Badano. 2005. Diversity of floral visitors to Echinopsis atacamensis subsp. pasacana (Cactaceae). Haseltonia 11: 18-26.

Schlumpberger, B.O., A.A. Cocucci, M. Moré, A.N. Sérsic \& R.A. Raguso. 2009. Extreme variation in floral characters and its consequences for pollinator attraction among populations of an Andean cactus. Annals of Botany 103: 1489-1500.

Valiente-Banuet, A., M.C. Arizmendi, A. Rojas- Martínez, H. Godínez-Alvarez \& P. DÁvila-Aranda. 2002. Biotic interactions and population dynamics of columnar cacti. In: T.H. Fleming \& A. Valiente-Banuet (eds.), Columnar cacti and their mutualists: evolution, ecology, and conservation. Pp 225-240. University of Arizona Press, Tucson.

Valiente-Banuet, A. F. Molina-Freaner, A. Torres, M.C. Arizmendi \& A. CASAS. 2004. Geographic differentiation in the pollination system of the columnar cactus Pachycereus pectenaboriginum. American Journal of Botany 91: 850-855.

WaLter, H.E. 2010. Floral biology of Echinopsis chiloensis ssp. chiloensis (Cactaceae): evidence for a mixed pollination syndrome. Flora 205: 757-763.

Recibido: 24.03 .11

Aceptado: 16.08.11 